\title{
Distribution of Changes in Systolic Blood Pressure and Waist Circumference - Indicators for Primary Prevention
}

\author{
Ksenija Vitale, Slavica Sović and Silvije Vuletić \\ University of Zagreb, School of Medicine, »Andrija Štampar« School of Public Health, Zagreb, Croatia
}

\begin{abstract}
A B S T R A C T
Eliminating or diminishing risk behaviors that lead to cardiovascular diseases could be achieved through primary prevention during the general practice visits. However, there is difference in effectiveness of preventive measure while there are no symptoms, and reactive response when burden of diseases start to show. We analyzed trends in gender and age- -pattern changes of systolic blood pressure and waist circumference, as a reflection of primary prevention. Results show increase of values for both indicators in both genders, through youngest and middle age groups. In the oldest group stagnation and even decrease of values is evident. These results signal possible absence of primary prevention in younger age groups and some action when symptoms occur. It is hard to distinguish weather lower values is consequence of medication or lifestyle change. The absence of primary prevention is usually missed opportunity that is charged later both to the patient and health care system.
\end{abstract}

Key words: waist circumference, systolic blood pressure, primary prevention

\section{Introduction}

There is a body of evidence showing that primary prevention can contribute to the changes in lifestyle that could otherwise lead to the cardiovascular diseases ${ }^{1-4}$. However, it is very important to stress the difference in effectiveness of preventive measures. Primary prevention that, generally, involves the prevention of diseases before their biological onset, while there are no symptoms of disease, is more effective, than reactive response when burden of cardiovascular diseases start to show. The absence of primary prevention is usually missed opportunity that is charged later both to the patient and health care system. In Croatia general practitioners (GP) often mix primary and secondary prevention and under primary prevention assume disease screening with follow-up of the findings and systematic examinations.

Waist circumference (WC) as indicator of abdominal obesity and systolic blood pressure (SBP) as key risk factor for cardio and cerebro-vascular diseases, are established indicators used in population health assessment, and changes in their distribution over the time could reflect general health trends and cardiovascular disease trends in various populations. Also they reflect weather existing primary prevention is well targeted and effective ${ }^{2}$

The aim of this article is to analyze the trends in gender and age-pattern changes of these two indicators as a reflection of primary prevention in general population. These results could help identify more effective strategies and implementation of national programs.

\section{Materials and Methods}

Data for this study were obtained from the Croatian Adult health Survey (CAHS) in 2003 followed by 2008 . Further details on CAHS are provided elsewhere ${ }^{5}$. Sample consisted of cohort of 3229 participants who were interviewed in both years. WC and SBP were analyzed by using percentile distribution at 5, 25, 50, 75 and 95 percentile points in years 2003 and 2008. The analysis was performed by gender and three age groups; up to 34 years, 35 to 64 years and over 65 years. Cut off values for WC were $88 \mathrm{~cm}$ for women and $102 \mathrm{~cm}$ for $\operatorname{man}^{6}$ and for SBP $140 \mathrm{mmHg}$ for both genders ${ }^{7}$. 


\section{Results}

Results are presented in figures 1-4. Values of SBP show same pattern of changes for both gender and age groups. Pattern of changes for the youngest and middle age group could be described as continuous shift of SBP to higher values, while for oldest group we can observe continuous shift to lower values. Increase between years is almost the same for both genders, but woman has lover values of SBP in the youngest age group than man. It is interesting that in the oldest group when both genders reached high values of SBP between 185 and $190 \mathrm{~mm} \mathrm{Hg}$, women have better results in lowering those values. Overall increase of SBP values was higher during the 2003 around 50\% and in 2008 that increase was lower around $30 \%$ (Figures 1 and 2).

Values for WC also show same, but increasing pattern, of changes for both gender and all age groups. In youngest age group the increase of population with over the recommended values is most dramatic $25 \%$ and in middle age group the increase between two periods is around $10 \%$ for females. In the oldest group values stagnate and increase is minimal Males are in general slimmer, and increase is around $12 \%$ in the youngest age

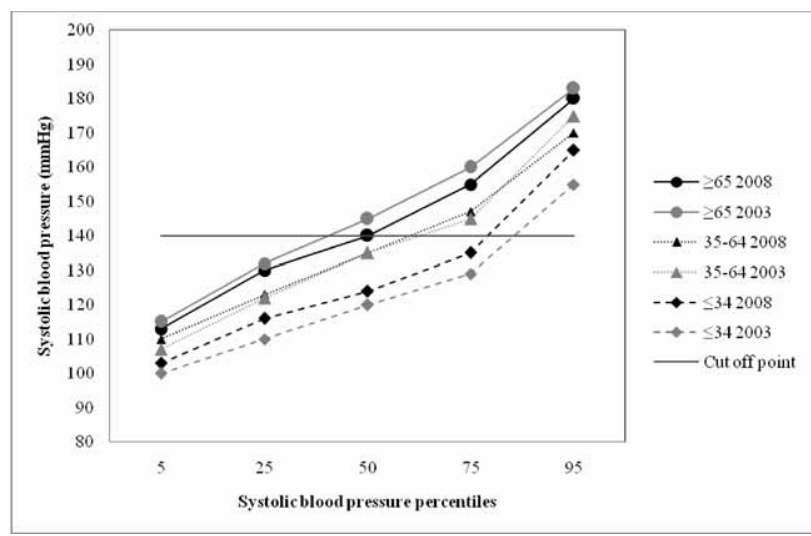

Fig. 1. Systolic blood pressure percentile distribution for man in $2003 \& 2008$.

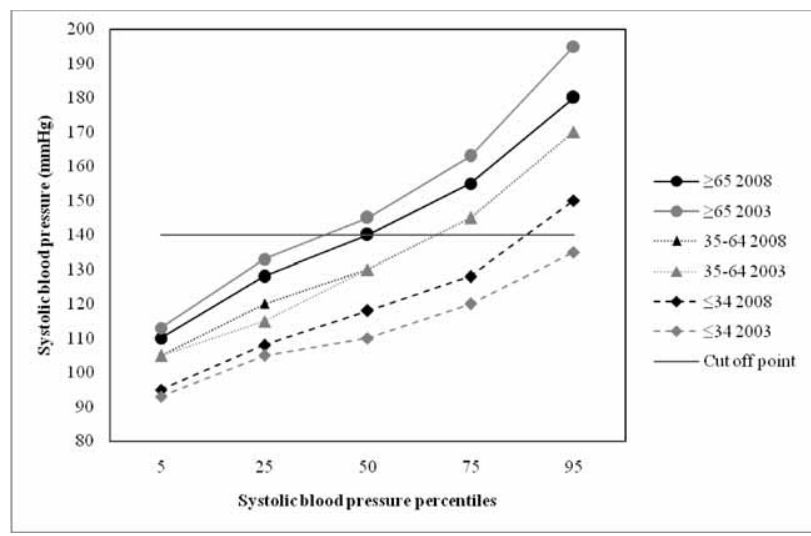

Fig. 2. Systolic blood pressure percentile distribution for woman in $2003 \& 2008$.

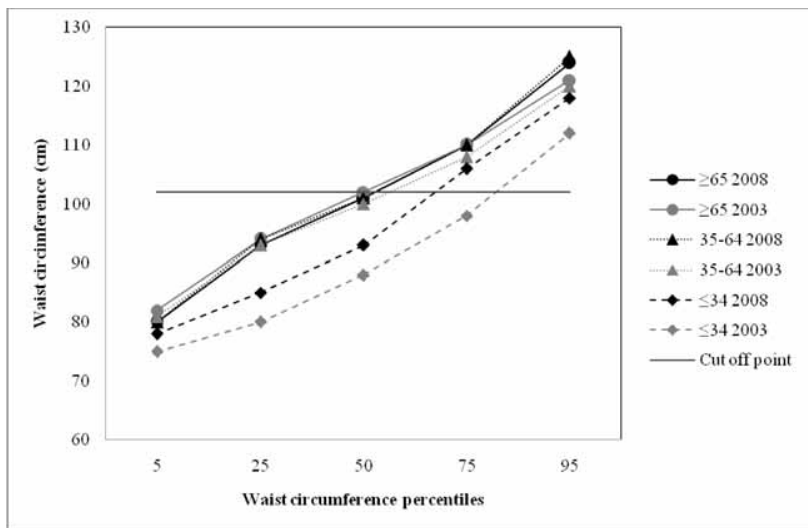

Fig. 3. Waist circumference percentile distribution for man in $2003 \& 2008$.

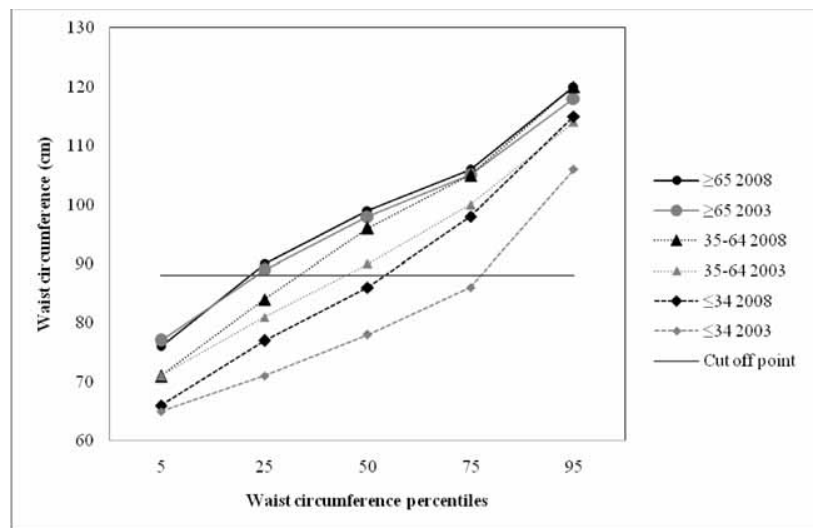

Fig. 4. Waist circumference percentile distribution for woman in $2003 \& 2008$.

group, in the middle and oldest age groups there are no changes. Women start increase in youngest group at $25^{\text {th }}$ and at this age around 50\% in 2008 had values higher than recommendations. This percentage is slowly increasing over the age and reaches $75 \%$ in oldest age group. Men show same increase trend at all percentiles in the youngest age group and in that group around 30\% are over recommended values. Across the age groups they stagnate and $50 \%$ are over recommended values in the middle and oldest age group (Figures 3 and 4). Slimmer women stay slim, while women with higher values of WC show higher increase over the time except for the oldest age group.

\section{Discussion}

While blood pressure is one of the oldest diagnostic tools, waist circumference is first introduced in mid nineties as the best anthropometric predictor for the cardiovascular risk. It soon became routine diagnostic tool thanks to its simplicity, velocity and almost no cost ${ }^{8-10}$. In Croatia according to the Plan and Program of measures for Healthcare ${ }^{11}$ primary prevention should be in- 
corporated in everyday practice of all GPs. While SBP is routinely measured at all visits it is unclear how often and to whom, WC is measured and if it is recorded in medical documentation. In authors personal experience WC was never measured. Our results indicate that most neglected are young age groups that do not show any response and where spontaneous grow of indicator values is present. This could be strong signal of non existing primary prevention in those groups. In women group we can observe highest increase in both indicators values, although the initial values were lower than in same age in man group. It seems that problem of WC is not adequately perceived, what could be explained by the fact that most women give birth in that period and that increase of abdominal fat is attributed to pregnancy and GPs feels there is no need for prevention or that gynecologist should address these deviations. One study showed that around $10 \%$ of women in Croatia gain more than 14 $\mathrm{kg}$ in pregnancy ${ }^{12}$. In the older age higher values are attributed to menopause. These results are in concordance with some other studies in Croatia that show that more advice is given to women in the middle age group with lower education, unemployed and housewives with higher body mass index and higher SBP than to younger women and unmarried woman. In the elderly group most advices get women who visit general practitioner the most ${ }^{13}$. This strongly reflect that GPs miss the idea of primary prevention and react when symptoms or disease occur. This could be explained with findings of Pavlekovic et al. that GPs in Croatia consider more important public health issued problems of alcohol and smoking than unbalanced nutrition or physical activity. Also they recognized more their role in secondary and tertiary prevention than in the primary, reporting lack of time, communication knowledge and incentives ${ }^{14}$. It is almost dangerous that GPs expect particular incentives for primary prevention. This could reflect commercialization of primary health care in Croatia and poorly regulated relations between health care system and pharmaceutical industry that offers interesting incentives for frequent drug prescription. Once, symptoms appear GPs automatically react with both counseling and medication. Similar results reported other authors in the world stressing that gender and age play one of the most important roles in advice giving in primary health care setting ${ }^{15-18}$. As oppose to that Lazic et al. describe positive experience in GP settings but as a behavioral therapy in small groups coordinated by GP. They showed decrease in body mass index of around $10 \%$ for both genders, but this is example of individual effort as secondary prevention, rather than systematic approach ${ }^{19}$. In the area of nutritional habits it seems that lifestyle counseling aimed at preventing weight gain, instead of weight loss, is more effective ${ }^{4}$.

Results show that values of SBP in oldest group decrease which could be explained by intervention when burden of disease start to show. It is hard to distinguish is this result of more advice giving for lifestyle change or medication, but we can say that certain proportion could have been prevented by primary prevention. Women show better results in lowering SBP values which could be explained by better compliance to the medication. Values for WC stagnate or slightly grow which could be explained only by some changes of lifestyle, and again medication, given the fact that in older age metabolism is slower and it is unlikely that older population could employ such a rigorous workout that would result in substantial weight loss.

There are not many analyses based on percentile distribution, two in USA and on in China, all analyzing data for more than ten years period showed that much of the waist circumference distribution has shifted towards highest values ${ }^{20,21}$. Authors suggest that primary prevention should be viewed as one of the major public health problems in the course of obesity epidemics. Still as an opened question remains whether we can all employ same cut off points or they differ across ethnic groups due to the different cardiometabolic risk.

The absence of primary prevention in Croatia especially to the younger age groups is missed opportunity for building positive and healthy society. In addition to that, missing on teaching healthy behavior habits to young women population is missing on teaching these behaviors even to next generations because women are those who transfer lifestyle to the whole family and next generations. Such a situation in our public health and primary health care should be changed systematically by creating more favorable climate for educating GPs, and better targeted population oriented national programs. Otherwise every missed opportunity is charged, at high cost, later both to the patient and health care system.

\section{Acknowledgements}

This study was supported by the Croatian ministry of Science, Education and Sport, grant number 1081080135-0264.

\section{R E F E R E N C E S}

1. EVANS A, TOLONEN H, HENSE HW, FERRARO M, SANS S, KUULASMAA K, WHO MONICA PROJECT, Int J Epidemiol, 30 Suppl 1 (2001) 35. - 2. FANANIAN M, LAWS RA, PASSEY M, McKENZIE S, WAN Q, DAVIES GP, LYLE D, HARRIS MF, BMC Fam Pract, 11 (2010) 57. - 3. NOORDMANJ, VERHAAK P, VAN DULMEN S, BMC Fam Pract, 11 (2010) 87. — 4. TER BOGT NC, BEMELMANS WJ, BELTMAN FW, BROER J, SMIT AJ, VAN DER MEER K, Arch Intern Med, 171 (2011) 306. - 5. VULETIĆ S, POLAŠEK O, KERN J, STRNAD M, BA-

KLAIĆ Ž, Coll Antropol, 33 Suppl 1 (2009) 3. - 6. Expert Panel on Detection, Evaluation, and Treatment of High Blood Cholesterol in Adults: Executive Summary of the Third Report of the National Cholesterol Education Program (NCEP) Expert Panel on Detection, Evaluation, and Treatment of High Blood Cholesterol in Adults. JAMA 285 (2001) 2486. - 7. MANCIA G, DE BACKER G, DOMINICZAK A, CIFKOVA R, FAGARD R, GERMANO G, GRASSI G, HEAGERTY AM, KJELDSEN SE, LAURENT S, NARKIEWICZ K, RUILOPE L, RYNKIEWICZ A, SCHMIE- 
DER RE, BOUDIER HA, ZANCHETTI A, J Hypertens, 25 (2007) 1751 - 8. HAN TS, VAN LEER EM, SEIDEL JC, LEAN MEJ, BMJ, 311 (1995) 1401. - 9. MOLARIUS A, SEI- DEL JC, SANS S, TUOMILETHO J, KUULASAMAA K, J. Clin Epidemiol, 52 (1999) 1213. - 10. POULIOT MC DESPRES JP, LEMIEUX S, MOORJANI S, BOUCHARD C, TREMBLAY A, NADEAU A, LUPIEN PJ, Am J Cardiol, 73 (1994) 460. - 11. MINISTRY OF HEALTH AND SOCIAL PROTECTION Official Gazzete 122/06, Available from URL: http:// narodne-novine.nnhr/default.aspx. - 12. MIKULANDRA F, PERISA M, MERLAK I, STOJNIC E, BALIC J, Zentralb Gynakol 115 (1993) 171. - 13. VITALE K, ŠULJIĆ P, DŽAKULA A, TODOROVIĆ G, VULETIĆ S, ČOVIĆ A, Coll Antropol, 33 Suppl 1 (2009)
165. - 14. PAVLEKOVIC G, BRBOROVIC O, Eur J Clin Nutr, 59 Suppl 1 (2005) 40. - 15. LIVAUDAIS JC, KAPLAN CP, HAAS JS, PEREZ-STABLE EJ, STEWART S, JARLAIS GD, J Womens Health 14 (2005) 485. 16. LITTLE P, SLOCOCK L, GRIFFIN S, PILLINGER J, Br J Gen Pract, 49 (1999) 806 — 17. JOHANSON K, BENDTSEN P, AKERLIND I, Eur J Public Health, 16 (2005) 615. — 18. AHACIC K, ALEBECK P, THAKKER KD, Subst Abuse Treat Prev Policy, 29 (2010) 5. - 19. LAZIC D, CIKAC T, OZVACIC Z, COP R, Acta Med Ceroatica, 61 (2007) 7. - 20. NESS-ABRAMOF R, APOVIAN CM, Nutr Clin Pract, 23 (2008) 397. - 21. WANG HJ, WANG ZH, YU WT, ZHANG B, ZHAI FY, Zhonghua Liu Xing Bing Xue Za Zhi, 29 (2008) 953.

\section{K. Vitale}

University of Zagreb, "Andrija Štampar« School of Public Health, Rockefeller st. 4, 10000 Zagreb, Croatia

e-mail:kvitale@snz.hr

\section{PROMJENA DISTRIBUCIJA SISOLIČKOG TLAKA I OPSEGA STRUKA - INDIKATORI PRMARNE PREVENCIJE}

\section{S A Ž E T A K}

Smanjenje ili eradikcija rizičnih ponašanja koji mogu dovesti do pojave kardiovaskularnih oboljenja može se postići primarnom prevencijom kroz rad liječnika obiteljske medicine. Važno je napomenuti da postoji kvalitativna razlika u savjetovanju kad simtomi bolesti još ne postoje i kad bolesnik već osjeća teret bolesti. Cilj ovog rada je razmotriti promjene dvaju indikatora kardiovaskularnih bolesti; sistolički tlak i opseg struka prema spolu i dobnim skupinama. Rezultati su pokazali porast vrijednosti za oba indikatora u oba spola te najmalađu i srednju dobnu skupinu. U najstarijoj dobnoj skupini vidljiva je stagnacija i/ili pad vrijednosti indikatora. Ovi rezultati signaliziraju mogući izostanak primarne prevencije u ovim dobnim skupinama i neku aktivnost kod pojave simptoma, ali je teško razlikovati da li je pad vrijednosti indikatora posljedica medikacije ili promjena životnog stila. Izostanak savjetovanja kao primarne prevencije može se smatrati izgubljenom prilikom koja se kasnije naplaćuje i bolesnicima i zdravstvenom sustavu. 